\title{
Article
}

\section{The Experience of using Facebook as an Educational Tool}

\author{
Prescott, Julie, Stodart, Matthew and Wilson, Sarah E \\ Available at http://clok.uclan.ac.uk/11548/ \\ Prescott, Julie ORCID: 0000-0001-8612-2495, Stodart, Matthew and Wilson, \\ Sarah E ORCID: 0000-0002-2875-0036 The Experience of using Facebook as \\ an Educational Tool. The Higher Education Academy . pp. 1-5.
}

It is advisable to refer to the publisher's version if you intend to cite from the work.

For more information about UCLan's research in this area go to

http://www.uclan.ac.uk/researchgroups/ and search for < name of research Group>.

For information about Research generally at UCLan please go to

http://www.uclan.ac.uk/research/

All outputs in CLoK are protected by Intellectual Property Rights law, including Copyright law. Copyright, IPR and Moral Rights for the works on this site are retained by the individual authors and/or other copyright owners. Terms and conditions for use of this material are defined in the policies page.

\section{CLoK}

Central Lancashire online Knowledge www.clok.uclan.ac.uk

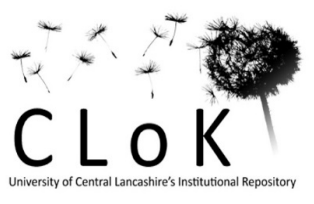




\title{
The Experience of using Facebook as an Educational Tool
}

\author{
Julie Prescott ${ }^{1}$, Matthew Stodart ${ }^{2}$, Gordon Becket ${ }^{2}$ \& Sarah Wilson ${ }^{2}$ \\ 'Department of Education and Psychology, University of Bolton, Bolton, BL3 5AB, UK \\ ${ }^{2}$ The University of Central Lancashire, School of Pharmacy, Mauldland Building, Preston, PR1 2HE, UK
}

\section{Corresponding author:}

Julie Prescott, Department of Education and Psychology, University of Bolton, Bolton, BL3 5AB, UK

Email: j.prescott@bolton.ac.uk, Phone: +44 (0) 1204 903676

\begin{abstract}
Social Networking Sites (SNS) such as Facebook are widely used by student populations and are increasingly used by the population generally. Researchers have considered the benefits of using SNS for educational purposes. This qualitative study involved interviews with seven academic members of staff at one UK university who currently use Facebook in their teaching. The study provides a unique insight into the views of teaching staff who use Facebook in their classroom, gaining an understanding of their experience and views of using SNS as part of their teaching.
\end{abstract}

Keywords: teaching, Social Networking Sites (SNS), Facebook, informal learning

\section{Introduction}

There is the suggestion that the Net Generation (those born in or after 1980) relies heavily on ICTs for social and professional interactions, and that they have the expectation that technology will be an integral part of their education (Oblinger \& Oblinger 2005, Barnes et al. 2007). However, there is a paucity of research which has considered educators' perspectives on integrating new digital media into the classroom (Mueller et al. 2008). In particular there is a lack of research looking at the educational use of social networking sites (SNS) such as Facebook (Vrocharidou \& Efthymiou 2012). Facebook is currently the most popular SNS (Facebook 2012) and the focus of the current research. Social media including SNS are now part of many people's everyday lives with active users, irrespective of age, using SNS such as Facebook and Twitter. 
Students need to be made more aware that their online behaviour leaves what has been termed a digital footprint (Mostaghimi \& Crotty 2011). Due to the popularity of SNS, previous research has considered the potential damage using such sites unprofessionally can have on students, through the disclosure of information and/or behaviour (Garner \& O'Sullivan 2010, Greysen et al. 2010), with studies suggesting there is a need for clearer guidelines for students about online professional behaviour (Greysen et al. 2010, Prescott et al. 2012).

Web 2.0 applications such as SNS offer new ways to communicate and transmit information. As such, Junco (2012) states that higher education staff have an opportunity to help students use Facebook and improve their overall academic experience. It has been posited that college and university students will soon demand the use of Web 2.0 technologies in their communications with staff (Hanny \& Fretwell 2010). Therefore it is viewed as paramount that more research into these technologies should be conducted in order to inform higher education teaching practices and investigate how Web 2.0 technologies can be utilised as teaching tools (Hicks \& Graber 2010).

Previous research has found that students tend to use SNS such as Facebook for more informal learning, such as communicating with peers about course content (Madge et al. 2009, Prescott et al. 2013). Facebook has been found to increase collaboration between students (Mazman \& Usluel 2010) and also increase the communication between student and lecturer (Bosch 2009). Another popular SNS is Twitter and research has found that this SNS tool can also enhance active and informal learning (Kassens-Noor 2012).

Many advocate the use of Facebook as a tool for learning due to the interaction, collaboration, information and resource sharing it can facilitate (Mazman \& Usluel 2010). Using Facebook as part of teaching has been found to enable quick and easy communication between teacher and student(s) (Bosch 2009). In order to successfully integrate the technologies into their teaching and learning strategies, educators need to understand and use social media such as Facebook (Vie 2008). Therefore it was felt pertinent and timely to investigate how a small sample of university teaching staff currently use Facebook in their teaching.

\section{Aim}

The aim of this study was to gain an insight of the experiences and views of academic staff who currently use Facebook as part of their teaching.

\section{Methods}

The study was qualitative in design. A search of Facebook university groups was undertaken to discover which teaching staff currently used the SNS with students. Once identified, staff were invited to take part in an interview. The inclusion criteria to take part in an interview were: teach as part of their job role and use SNS as part of their teaching methods. Seven semi-structured interviews were conducted during July and August 2012. The interviews took between 20 and 45 minutes. All the interviews were digitally recorded, transcribed verbatim and analysed thematically using NVivo version 4. All participants volunteered to take part in the study. Participants were from different schools across the university including psychology, pharmacy, and journalism. Four of the participants were female and three male, aged between 30 and 55. The number of years participants had taught at the university varied with the shortest being three years and the longest 24 years. The interview schedule included: how lectures use Facebook in their teaching, why they use Facebook as part of their teaching, what they viewed as the benefits to using Facebook this way, if they have come across any drawbacks with using Facebook as part of their teaching/course, and if they had seen inappropriate comments or behaviour posted by students. Ethical approval was received from the University Ethics Committee.

\section{Findings}

All seven participants had a group page on Facebook for their course or a specific module. However, the aim of the group differed from course module groups, a course feedback group, an alumni group, and a course discussion group. When asked why they used Facebook as part of their teaching, all participants viewed Facebook as a good site to communicate with students as all their students used Facebook. For example:

With Facebook the majority of them are accessing that numerous times daily, so I can get through to them without them feeling they have to log on to something else. (Interview 1)

The vast majority of students are on Facebook. I knew they were using it to coordinate coursework and stuff like that so I thought I may as well put myself in the middle of that. (Interview 7)

With regards to the benefits of using Facebook as part of their teaching, the main benefit was communication because their students used it and 
accessed it daily, therefore staff found using Facebook as an easier and much quicker way to contact students. Another benefit was that it enabled course discussions to continue outside of the classroom. It was also viewed as beneficial because it was a platform students already used and were familiar with. These benefits are illustrated by the following quotes:

Facebook is a really good way of keeping a classroom discussion going, and everybody is logging on and posting stuff. (Interview 2)

Well, the benefit really is what I've described in keeping in touch with students; the great thing about Facebook is that it's a medium which young people are enthusiastic about, so it's a far better way to keep in touch than simply emailing them or expecting them to follow a blog. (Interview 5)

The participants all viewed using Facebook for educational purposes as beneficial to the students, in that students are able to keep in contact with each other as well as the course lecturer. Lecturers felt class engagement had increased, and that all can share information and course related resources, for example;

It's a means by which the neuroscience students can support each other throughout the course. It's a place which I can place interesting neuro news, career and volunteer opportunities and placements - those kind of things. (Interview 1)

In terms of engagement, I would say direct engagement with the class has gone up and I have probably spoken to them more. (Interview 7)

I have posted things on Facebook and they have asked about them in class, so there is definitely a follow on from that. (Interview 3)

The drawbacks mentioned by participants included: getting friend requests from students outside of the course/module group, the awareness that not all students are on Facebook, and that students use Facebook too much. For example:

Yes, I have had more friend requests because people see you on Facebook and therefore think you can be friended. (Interview 3)

The other danger from using Facebook, or any social media, is that it can never replace one-on-one interaction; it's too easy for students to use emails or use Facebook to message people and they sit and wait. I'm talking about the professional aspects in that they don't develop enough as journalists. Facebook's a great tool, it is a really great tool, because it does help them to make contact in ways that they couldn't do otherwise, but sometimes they depend on it too much. (Interview 5)

Staff had seen inappropriate behaviour on Facebook for instance:

Well, the very first year I did it because I added them as friends. I didn't realise the sort of things people posted on Facebook and I had been put in a position where I'd seen people discussing illegal activities, which would be fitness to practice issues. Even though I did say to the students, 'look I'm not interested in what you do, not interested in your photos, what you get up to', I didn't realise when I log in I can see a wall of all their comments and some of the stuff really was not appropriate. (Interview 4)

With this case no action was taken, although students involved have since been removed from the course. With other incidents of inappropriate behaviour, calling the students into the office and explaining that this was not what the Facebook group was for had been enough to stop it happening:

We had to pull in a couple of students in and say 'this is not what this page is for so please stop doing that', but this is the first time we have ever had that, and until now it's worked fine and they haven't done it since. It was just a case of them getting out of control and me reining them back in. (Interview 2)

Participants were aware of online professionalism and the digital footprint. All seven of the participants informed their students about the digital footprint or conducting themselves professionally online either through employability modules, or through talking directly to their students, and they informed their students of this:

What I said to my students is 'if you saw yourself on Facebook would you give yourself a job?' and nine times out of ten they said they wouldn't. (Interview 7)

Staff were also aware of their own online professionalism:

I don't post anything personal on it; it's pretty much always to do with work in some regard or other. (Interview 2)

If you're pretending to be one person as a journalist and then somebody goes on your 
Facebook page and you're a drunken idiot, then that undermines your profession. You have to look at how you want to be perceived and how you are perceived through your behaviour - so it's not just on Facebook, but it's how you conduct yourself professionally. (Interview 7)

The participants were all asked to comment on the following statement: 'It has been said that the Internet blurs the line between what is personal and what is professional'. All agreed with the statement. However, participants tended to view this as both positive and negative, for example:

My view on that would be yes it does, which is a good thing and a bad thing, because people have relationships with many different people in different contexts more so now because of SNSs. (Interview 5)

I think there are benefits to it blurring and there are drawbacks ... it's about managing the expectations and if people's expectations are set early it doesn't become a problem; if anything set the ground rules from day one. (Interview 6)

\section{Discussion}

Findings from this study of teaching staff that currently use Facebook as part of their teaching suggests that from their experiences there are more benefits than drawbacks. In particular, Facebook was viewed as enhancing the communication between lecturer and student, which was viewed as a reciprocal benefit. This supports previous research by Bosch (2009). Facebook was also viewed as beneficial in that it increased and enhanced the student experience through class discussions outside of the classroom. Again, supporting the argument made by Madge et al. (2009) and later supported by Prescott et al. (2013) that the use of SNS helps increase students informal learning; in particular their communication about course content. This informal learning possibly provides students with improved learning as well as enhancing their overall student experience. However, participants were aware of the importance for both lecturer (staff) and student to be conscious of their digital footprint and adhere to professional standards online, as well as to provide students guidance in their online professionalism. Again, this supports previous research in the area such as Prescott et al. (2012) who found pharmacy students need more guidelines on how to behave professionally online. In fact it could be argued that using Facebook in the classroom provides teaching staff with a good opportunity to discuss online professional behaviour, the implications of being online and the digital footprint with their students.

Despite the findings there are a number of limitations to the study. Firstly, the study was conducted with staff from one university. Secondly, the study would have benefited from a greater understanding of the courses that the teaching staff used SNS on, as well as the course content. This could help provide a greater understanding of the actual teaching methods employed using SNS and help others considering the use of SNS implement it in their teaching. Thirdly, it would have been beneficial to interview students who attended the courses in order to gain their perspective of the use of Facebook as an educational tool and the possible benefits and drawbacks they perceived with its use in the classroom.

It must also be remembered that although Facebook is highly popular with student populations, and for the staff in the current study, all their students used Facebook regularly. However, not all students will have a Facebook account and use the site. This is a major consideration for teaching staff when planning to use the tool for educational purposes.

\section{Conclusion}

Despite the studies limitations, the study offers a unique look at the use of Facebook as an educational tool from the perspective of university staff who currently use the SNS to varying extents in their teaching practice. The research tends to support previous research in that teaching staff felt the benefits of using Facebook as an educational tool increased communication between themselves and the students and that its use also increased students informal learning, in particular discussions of course content outside of the classroom. It is apparent from the research that overall, teaching staff viewed more benefits to using SNS than drawbacks. Due to the impact of Web 2.0 technologies in the everyday lives of students, it is important that teaching staff and university staff generally consider its use in the learning context. More research is needed to look at how Facebook and other SNS might be used within the classroom and as part of educational practice, in order to both enhance the student experience and encourage more novel ways of student engagement and learning.

\section{Acknowledgements}

We thank the School of Pharmacy and Biomedical Sciences at UCLan for supporting this project. None of the authors have any conflicts of interest in writing this article. 


\section{References}

Barnes, K., Marateo, R.C. and Ferris, S.P. (2007) Teaching and learning with the Net generation. Innovate 3 (4), 1-8.

Bosch, T.E. (2009) Using online social networks for teaching and learning: Facebook use at the University of Cape Town. South African Journal of Communication Theory and Research 35, 185-200.

Facebook (2012) Facebook a year in review 2012. Available at https://www.facebook.com/press/info. php?statistics\#!/press/info.php?statistics (accessed 28 April 2013).

Garner, J. and O'Sullivan, H. (2010) Facebook and the professional behaviours of undergraduate medical students. The Clinical Teacher 7, 112-5.

Greysen, S.R., Kind, T. and Chretien, K.C. (2010) Online professionalism and the mirror of social media. Journal of General Internal Medicine 25, 1227-9.

Hanny, M. and Fretwell, C. (2010) The higher education workplace: meeting the needs of multiple generations. Research in Higher Education Journal 10, 1-12.

Hicks, A. and Graber, A. (2010) Shifting paradigms: teaching, learning and Web 2.0. Reference Services Review 38 (4), 621-633.

Junco, R. (2012) The relationship between frequency of Facebook use, participation in Facebook activities, and student engagement. Computers and Education 58 (1), 162-171.

Kassens-Noor, E. (2012) Twitter as a teaching practice to enhance active and informal learning in higher education: the case of sustainable tweets. Active Learning in Higher Education 13 (1), 9-21.

Madge, C., Meek, J., Wellens, J. and Hooley, T. (2009) Facebook, social integration and informal learning at university: 'It is more for socialising and talking to friends about work than for actually doing work'. Learning Media and Technology 34 (2), 141-155.

Mazman, S.G. and Usluel, Y.K. (2010) Modeling educational usage of Facebook. Computers and Education 55 (2), 444-453.

Mostaghimi, A. and Crotty, B.H. (2011) Professionalism in the digital age. Annals of Internal Medicine 154, 560-2.

Mueller, J., Wood, E., Willoughby, T., DeYoung, T., Ross, C. and Specht, J. (2008) Identifying discriminating variables between teachers who fully integrate computers and teachers with limited integration. Computers and Education 51, 1523-1537.

Oblinger, D. and Oblinger, J. (2005) Is it age or IT: first steps toward understanding the Net generation. In Educating the Net Generation (ed. D. Oblinger and J. Oblinger), pp2.1-2.20. Boulder, CO: EDUCAUSE.

Prescott, J., Wilson, S. and Becket, G. (2012) Pharmacy students want more guidelines on Facebook and online professionalism. The Pharmaceutical Journal 289 (4), 163.

Prescott, J., Wilson, S. and Becket, G. (2013) Facebook use in the learning environment: do students want this? Learning, Media and Technology doi:10.1080/17439884.2013.788027.

Vie, S. (2008) Digital divide 2.0: "generation M" and online social networking sites in the composition classroom. Computers and Composition 25 (2), 9-23.

Vrocharidou, A. and Efthymiou, I. (2012) Computer mediated communication for social and academic purposes: profiles of use and university students' gratifications. Computers and Education 58 (1), 609-616. 